\title{
М. Почапська
}

\section{РЕПЕРТУАР ЯК ПОЛІТИКА: ЗМІНИ В МУЗИЧНОМУ ЖИТТІ ЛЬВОВА ПІСЛЯ ВЕРЕСНЯ 1939 РОКУ}

\begin{abstract}
Тоталітарна держава неодмінно намагається контролювати думки й почуття своїх підданих щонайменше настільки ж, наскільки контролює їх учинки.
\end{abstract}

Джорджс Орвелл ${ }^{1}$

\begin{abstract}
Пропонована стаття присвячена детальному розгляду та аналізу репертуару львівської філармонії та оперного театру (на прикладі публікацій в львівських радянських газетах «Вільна Україна», «Ленінська молодь» $i$ «Czerwony sztandar»). Основна мета: виявити впливи, пов'язані зі зміною влади, як і в музичній репертуарній політиці, так і в художньому контексті в цілому.
\end{abstract}

Ключові слова: музична критика, музична публіцистика, оперний репертуар, ідеологія, соцреалізм, В. А. Барвінський.

У Львові та інших містах Західної України здавна існували численні культурні традиції, були окремі мистецькі осередки, що відігравали дуже важливу роль у розвитку духовного життя суспільства. Після приходу радянської влади до Львова у 1939 р. для ефективної роботи у всіх культурних ділянках були фактично наново організовані творчі, мистецькі заклади та лабораторії, деякі з них - просто реорганізовані (як, наприклад, Державна консерваторія, яка утворилася 1939 р. на базі трьох вищих музичних закладів Львова). Саме з цієї причини так впевнено декларуються численні постанови щодо організації нових мистецьких та навчальних музичних закладів. На початок 1940 р. у Львові почали діяти наступні інституції: Львівська радіостанція (з музичним відділом), Симфонічний оркестр філармонії, Державна академічна капела «Трембіта», Львівський академічний театр опери та балету, Львівська консерваторія та деякі інші. Усі ці заклади та установи практично уже існували, проте новий уряд намагався створити «видимість» самого факту організації культурного життя у Львові та його позитивного впливу на розвиток мистецтва.

3 огляду на тематику представленого дослідження детальніше зупиняємось на огляді мистецького життя Львова в період приходу ра-

\footnotetext{
${ }^{1}$ Орвелл Дж. Література і тоталітаризм (цит. за: [3, с. 35 ]).
}

(C) Почапська М., 2015 
дянської влади (1939-1941рр.), зокрема репертуару Львівської філармонії та оперного театру, який був створений на основі зліквідованої попередньої театральної установи - Театру Великого - та отримав назву Державний український театр опери та балету.

31934 р. був закритий через фінансову скруту. Про відновлення роботи театру пише Василь Барвінський у львівській пресі: «Передача радянською владою будинку Великого театру для користування театрові опери та балету для Львова має величезне мистецьке значення. Факт, що з львівської оперної сцени, вперше в історії лунатиме українська мова. І все те стало дійсністю тільки тепер, за радянської влади, в рік звільнення Львова героїчною Червоною армією» [6].

Це установа, колектив котрої 1939 року складався із 215 осіб, а після напруженої розбудови в серпні наступного року налічував уже 500 осіб. Серед солістів переважали польські артисти - Францішка Слонєвська (Franciszka Słoniewska), Валерія Єнджеєвська (Waleria Jędrzejewska), Ромуальд Циганік (Romuald Cyganik), Францішек Бедлевіч (Franciszek Bedlewicz), Єжи Фітьо (Jerzy Fitio), Лешек Рейхан (Leszek Rejchan), Coфія Чепєлювна (Zofia Czepielówna). Головним декоратором та художником-постановником театру був відомий львівський художник Фелікс Вигживальський (Feliks Wygrzywalski) [5, с. 111].

Також тут працювали режисери Олександр Улуханов, А. Лейн та В. Манзій, художники О. Хвостов (з Харкова), М. Ушин (з Ленінграду). Відтак серед числа солістів здебільшого збереглись місцеві виконавці, натомість режисери та художники-постановники були запрошені з інших міст Радянського Союзу. Серед них, зокрема, Олександр Улуханов - режисер та співак, представник московської школи. До роботи у Львові працював з антрепризами у Казані, Саратові, Києві, Тбілісі, Баку, Одесі, Санкт-Петербурзі; провадив режисерську діяльність у Києві, Петербурзі, Свердловську; у 30-х рр. - режисер «Російської опери» у Парижі. «Львівський оперний стає важливим осередком культурного життя краю, і слава про нього поширюється по всій Європі», - підкреслює А. К. Терещенко [4, с. 7]. Адже ще з часів його заснування (1900р.) тут співали відомі оперні виконавці, серед яких Олександр Мишуга, Модест Менцинський, Соломія Крушельницька та інші.

Відтак театр володів величезним робочим та мистецьким складом, тут працювала «зіркова» плеяда з різних національних шкіл (польська, єврейська, українська тощо).

Відкриття відбулося у вересні оперою Івана Дзержинського «Тихий Дон». Вочевидь, не випадково саме соцреалістичною оперою ра- 
дянського композитора, на сьогоднішній день зовсім маргінального. Колектив очолив головний диригент опери М. Покровський. Окрім нього працювали диригенти Юзеф Лерер та Якуб Мунд. Останній (єврейського походження) згодом був розстріляний німцями 1943 р. у Янівському концтаборі під Львовом, де перед тим керував табірним оркестром.

Як зазначає Гжегож Грицюк (Grzegorz Hryciuk) у своїй роботі «Polacy we Lwowie 1939-1944. Życie codzienne»: «культурне життя театральне і музичне - у Львові, під час радянської окупації 19391941 pр., було оживлене. Радянська влада намагалася внести у цю ділянку відчуття певного позитиву і навіть розквіту» [5, с. 112]. Неабияку роль в цьому відігравала преса, котра з приходом радянської влади стала чи не основним знаряддям впливу на свідомість суспільства. Оскільки система політичної цензури стала всеохопною, випуск книжково-журнальної та газетної продукції без попередньої цензури та детальної перевірки заборонявся. Підтримку влади одержало лише обмежене коло авторів, які, намагаючись працювати в руслі канонів «соціалістичного реалізму», прийняли «радянську платформу». 3 огляду на це у львівській пресі масово висвітлюється культурне життя міста. Філармонічні концерти, гастролі відомих виконавців, оперні прем'єри - повідомлення про ці події швидкими темпами друкуються на шпальтах періодичних видань. Музично-критичні публікації дуже часто зустрічаються у трьох львівських газетах, що існували на той час: україномовних «Ленінська молодь» та «Вільна Україна» та польськомовній «Czerwony sztandar». На основі порівняльного аналізу цих газет можна зробити висновок про активне мистецьке життя міста. На сценах концертних залів Львова (1939-1941 рр.) виступали славетні радянські виконавці, такі як: піаністи - професор Абрам Луфер, Яків Флієр та Ісаак Міхновський, лауреат Всесоюзного та Міжнародного конкурсу піаністів Яків Зак, скрипалі - Давид Ойстрах і Михайло Фіхтенгольц. Гастролювали у Львові композитори Рейнгольд Глієр, співаки - Давид Бадрідзе, Марія Литвиненко-Вольгемут, Іван Паторжинський, Михайло Донець, Оксана Петрусенко; народна артистка Узбекської РСР Тамара Ханум, славетна польська співачка Єва Бандровська-Турська.

Зазвичай подібні заходи та мистецькі акції знаходили своє вербальне відображення на сторінках львівської преси. Наприклад, про приїзд знаменитого радянського скрипаля Давида Ойстраха (у квітні 1941 р.) заздалегідь були надруковані анонси у трьох щоденних львів- 
ських газетах. Відомо, що музикант дав у Львові два концерти. На першому, як повідомляється у рецензії, скрипаль виконав «низку вдалих «nереробок» [11]. В іншому концерті Д. Ойстрах подарував львівській публіці інтерпретацію скрипкового концерту D-dur П. Чайковського. I як зазначає рецензент, «враження від виконання цього концерту було для всіх незабутнє» [11].

Обов'язковим атрибутом концертного життя у той час були мистецькі заходи з політичним підтекстом. Одним із таких є серія філармонічних концертів під назвою «дакади радянської музики» або ж концерти чи інші заходи, присвячені святкуванню «важливих» (радянських) річниць, першотравневих свят і т. п. - 3 типово ідеологічним підходом. На одному із таких концертів виступив директор Київської консерваторії, професор і піаніст Абрам Луфер, де виконав ряд фортепіанних творів Л. Ревуцького, зокрема його Концерт для фортепіано з оркестром, та познайомився з діяльністю музичних закладів Львова.

Львів гостинно приймав гостей, гастролерів та відомих музикантів, і завжди щедро нагороджував своїми оваціями і підтримкою. Практично кожен виконавець, який побував тут, майже завжди 3 любов’ю згадує теплі зустрічі з львівською публікою. Так писала відома польська співачка Єва Бандровська-Турська після свого концерту у Львові: «Я ніколи в моєму житті не мала таких уважних і музикальних слухачів, як у Радянському Союзі. Це справді країна радості, пісні і музики. Трудящі радянських міст вміють цінувати мистецтво» [10]. Слід зауважити, що у наведеній цитаті яскраво прослідковується ідеологічна інтерпретація журналістського жанру.

Тим не менше, завдяки музично-критичним публікаціям та рецензіям можна прослідкувати за усіма метаморфозами і в оперному репертуарі у представлений період. Детально опрацювавши публікації в пресі, наводимо список вистав, які були в репертуарі Львівського театру від вересня 1939 р. до червня 1941 р., в хронологічному порядку:

1939 р. - «Пікова Дама» П. І. Чайковського; «Запорожець за Дунаєм» С. С. Гулака-Артемовського; балет «Лауренція» О. А. Крейна;

1940 р. - «Тихий Дон» І. Дзержинського; «Травіата» Дж. Верді; «Евгеній Онєгін» П. І. Чайковського; балет «Дон Кіхот» Л. Мінкуса; «Мадам Баттерфляй» і «Богема» Дж. Пуччіні.

1941 р. - «Наталка Полтавка» М. Лисенка в оригінальній редакції В. Г. Костенка; балет «Червоний мак» Р. Глієра; «Кармен» Ж. Бізе; «Циганський барон» Й. Штрауса. Останньою роботою колективу те- 
атру мала стати постановка українського балету К. Данькевича «Лілея», про що повідомляла львівська газета «Вільна Україна» (за 20 червня 1941 р.). Проте ії̈ прем’єру (до якої плідно і активно тривала підготовка) перервала війна. Окрім того, в одній із публікацій газети «Вільна Україна» про «відкриття оперного сезону у Львові» знаходимо затверджений план репертуару на 1940-1941 pp. Серед непоставлених, але запланованих перед війною спектаклів, є опери «Тарас Бульба» М. Лисенка, «Аїда» Дж. Верді, «Корневільські дзвони» Робера Планкетта, «Мадам Анго» Шарля Лекока, музика до драми Островського «Снігуронька» за Чайковським, сценічна постановка драми «Пер Гюнт» Е. Гріга.

Багатий репертуар театру, наповнений, відтак, різноманіттям національних шкіл та контрастом жанрів - від легких оперет і балетів до лірико-драматичних опер. Однак червоною ниткою в репертуарі проходять опери в стилі соцреалізму (як наприклад, «Тихий Дон»), радянські балети про нерівність класових верств населення, буржуазію і т. п. Якраз в цьому і полягала набільша функція ідеологічної машини в сфері культури - заангажованість суспільства масовим мистецтвом радянського спрямування на новоопанованих територіях, для публіки, котрій потрібні були нові ідеологічні переконання.

Як було зазначено вище, усі постановки львівської опери одразу ж фіксувались у вигляді розширених публікацій в пресі: анотаційповідомлень про майбутню прем'єру та рецензію на неї. Найбільший парадокс полягає у тому, що саме «радянські» опери та балети отримували високопрофесійну оцінку в пресі, часто з кількома статтями, написаними професійними критиками. Найчастіше в ролі останнього виступав композитор, директор львівської консерваторії В. Барвінський. Наприклад, прем'єрі опери «Тихий Дон» Івана Дзержинського, в газеті «Вільна Україна» було присвячено чотири великі статті різних авторів (на двох сторінках номеру). Серед них масштабна фахова стаття В. Барвінського. Не випадково Львівський театр розпочав свій концертний сезон цією оперою, адже це твір, в якому радянський композитор Іван Дзержинський ${ }^{1}$

\footnotetext{
${ }^{1}$ «Тихий Дон» - перша опера композитора, і за рекомендацією Д. Шостаковича була включена в план Ленінградського малого театру опери та балету, в жовтні 1935 р. поставлена і незабаром увійшла до репертуару багатьох музичних театрів країни. Перше видання клавіру вийшло з присвятою опери Д. Шостаковичу. При повторному його виданні І. Дзержинський зняв присвяту під впливом редакційної статті «Сумбур замість музики» в газеті «Правда».
} 
яскраво втілив основні постулати панівного на той час стилю соцреалізму.

Як зазначає А. Терещенко, з часу іiі прем'єри в Малому театрі «опера «Тихий Дон» ставиться в багатьох театрах країни, маніфестуючи реалістичні засади сучасної опери, «нову інтонацію», почуту в живому плині народнопісенної мови. Вистава, підготовлена молодою трупою львівського театру, пройшла з успіхом і мала гучний резонанс» [4, с. 10-11] Творчий склад опери в основному залишається той самий, що і в попередніх постановках. Окрім вже знайомих прізвищ - М. Трегубова, А. Улуханова, М. Покровського, Ф. Слоневської, Ф. Бедлевича, Л. Ландау, Р. Циганіка - автор рецензії А. Лєв («Czerwony sztandar») наголошує на хорошій роботі декоратора Хвостова. Загалом надруковані доволі позитивні та схвальні рецензії, що свідчать про великий успіх опери. Тільки В. О. Барвінський у своїй статті доволі недвозначно назвав іiі «повноцінним спектаклем» [9]. Очевидно, що рецензування творів на подібну тематику потребувало найбільш талановитих критиків, майстрів слова, котрі мають авторитетну думку, а також посідають важливе місце в суспільному житті. Василь Барвінський, як відомий композитор, музичний діяч, директор Львівської консерваторії (на той час), відтак, успішно виконав місію музичного критика, продемонструвавши усю майстерність свого пера. «Тихий Дон» - це одна із найбільш вдалих спроб дати класичну по формі радянську оперу. Ї̈ лібрето основано на тлі роману Шолохова, під иією жк назвою, в якому особиста трагедія героїв тісно в'яжеться з великими історичними подіями, які до основ струснули старий світ гніту і експлуатації» [9]. Дуже влучно і коректно він критикує музичну сторону опери, даючи слушні та обгрунтовані зауваження: «Сама музична мова не посідає ще якихсь виразних індивідуальних рис і не претендує на новаторські тенденції. Проте, вже в цій першій спробі молодого композитора відчуваємо інколи новий колорит, так характерний для кращих масових радянських пісень» [9].

Подібне завдання, мабуть, було у Барвінського при написанні рецензії на постановку балету Людвіга Мінкуса «Дон Кіхот». Найбільша складність представленої статті полягала, насамперед, у майстерності дати не занадто критичну, позитивну оцінку на постановку цього балету. Про сумнівність художної якості музичного полотна В. Барвінський пише відкрито, проте коректно: «Надавати музиці Мінкуса, написаній для балета «Дон Кіхот», якогось мистещького серйозного значення не слід, бо ні формою, ні змістом ці поодинокі, майже не зв'язні 
між собою музичні номери, не викликають зацікавлення» [7]. Тим не менше, у двох інших рецензіях на цю постановку в газетах «Ленінська молодь» та «Czerwony sztandar» ніхто з авторів не насмілювалися висловлювати саме такі думки. А навпаки - були надто щедрими у своїх судженнях, позитивно формулюючи музично-критичну оцінку роботи колективу та музику композитора загалом. В. Барвінський же акцентує свою увагу на величезному значенні іншого факту. Музична сторона твору набула значно якіснішої форми у редакції композитора Ю. Кофлера, котрий «зумів усі поодинокі музичні номери зв'язати в більш органічно-злитий твір, написавщи до нього пролог і епілог та кілька вставок» [7].

Важливою подією для Львова став приїзд композитора Райнгольда Глієра. Про це йдеться в рецензії на постановку його балету «Червоний мак». «Ім'я композитора Глієра є відоме і широко популярне у всьому Радянському Союзі. Наше місто недавно мало честь гостити його у себе, і пізнати його як диригента і композитора симфонічної музики. «Червоний мак» (1926-27 рр.) - перший балет, оснований на радянських мотивах, перша вдала спроба створення нової форми радянського балету» [12].

Про факт приїзду Р. Глієра до Львова пише і В. Барвінський. У своїй рецензії на постановку його балету композитор говорить, що «це перша вдала спроба створити балет на радянську тематику» [8]. А найкрашим репрезентантом є вислів, який висвітлює великий вплив ідеології на митця: «3 новим розмахом та розквітом музичної культури Львова, що почався з дня встановлення радянської влади на землях Західної України, ряди видатних музичних діячів, композиторів та виконавців помітно зросли» [8].

Дослідивши культурно-мистецькі матеріали львівських щоденних газет (за 1939-1941рр.), можна зробити певні висновки щодо музичного, та й загалом, мистецького життя Львова. Різка зміна політичної ситуації в Галичині відобразилася на культурному житті регіону і на його інтерпретаціях у періодиці. Подібні публікації дають усі підстави вважати мистецтво ідеологічною зброєю у руках тих, хто ним керує. Особливо, якщо це масове мистецтво, де звичайний концертний репертуар виступає лише як засіб поступового впливу з метою виховати «нову людину» та побудувати «нове суспільство». Українська незалежність дала можливість об'єктивно оцінити досліджуваний період, відкинувши ідеологічні догми. 


\section{СПИСОК ЛІТЕРАТУРИ}

1. Булка Ю. П. Вплив радянського мистецтва на розвиток музичної культури західноукраїнських земель у 20-30 роки / Юрій Булка // Українське музикознавство. - 1977. - Вип. 14 - С.48-59.

2. Культурне життя в Україні. Західні землі: документи і матеріали / упор.: Тамара Галайчак, Олександр Луцький, Богдан Микитів, Людмила БатракПлодиста, Юрій Сливка, Лев Федоришин. Том 1: (1939-1953). - К. : Наукова думка, 1995. - $748 \mathrm{c.}$

3. Потятиник Б. В. Тоталітарна журналістика: текст лекцій / Потятиник Б. В. - Львів : Ред.-вид. відділ, 1992. - 80 с.

4. Терещенко А. К. Львівський державний академічний театр опери та балету імені Івана Франка / Алла Терещенко. - К. : Музична Україна, 1989. $208 \mathrm{c}$.

5. Hryciuk G. Polacy we Lwowie 1939-1944. Życie codzienne / Grzegorz Hryciuk. - Warszawa : Książka i wiedza, 2000. - 430 s.

6. Барвінський В. Велика культурна подія // Вільна Україна. - 1940. № 121,26 травня.

7. Барвінський В. «Дон Кіхот», у Львівському державному театрі опери та балету // Вільна Україна. - 1940. - № 257, 1 листопада.

8. Барвінський В. Композитор Р. М. Глієр у Львові // Вільна Україна. 1941. - № 40, 18 лютого.

9. Барвінський В. Повноцінний спектакль // Вільна Україна. - 1940. № 224, 24 вересня.

10. Колесніченко П. Гастролі артистки Єви Бандрівської-Турської // Вільна Україна. - 1940. - № 2, 3 січня.

11. Старлінг А. Концерти Давида Ойстраха // Вільна Україна. - 1941. № 79, 4 квітня.

12. Mantel W. «Czerwony mak». Z teatrzu Opery i Baletu // Czerwony sztandar. - 1941. — № 70, 25 marca.

Почапская М. Репертуар как политика: изменения в музыкальной жизни Львова после сентября 1939 года. Предлагаемая статья посвящена детальному рассмотрению и анализу репертуара Львовской филармонии и оперного театра (на примере публикаций в львовских советских газетах «Свободная Украина», «Ленинская молодежь» и «Czerwony sztandar»). Основная цель: выявить влияния, связанные со сменой власти, как в музыкальной репертуарной политике, так и в художественном контексте в целом.

Ключевые слова: музыкальная критика, музыкальная публицистика, оперный репертуар, идеология, соцреализм, В. Барвинский.

Pochapska M. Repertoire in terms of policy: changes in the musical life of Lviv since September 1939. The focus of this article is consideration of music-critical activities of Lviv artists in totalitarian regime conditions. Among them - composers 
V. Barvinsky, V. Vytvytsky and musicologists Z. Lissa and S. Lobachevska. Are analyzed selected music-critical publications in Lviv Soviet press, 1939-1941 years ukrainian newspapers «Free Ukraine», «Leninist youth» and polish «Red flag».

Keywords: musical critics, musical publicism, ideology, V. Barvinsky.

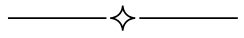

УДК $78.03+782.1$

\section{B. Мищук}

\section{ОПЕРА «ДОН КИХОТ» К. АЛЬФТЕРА: ТРАДИЦИОННОЕ И НОВАТОРСКОЕ В ТРАКТОВКЕ «ВЕЧНОГО» ОБРАЗА}

В статье анализируются идейно-композиционные, драматургические основы и стилевые параметры оперы «Дон Кихот» современного испанского композитора Кристобаля Альфтера. Противопоставление атональных (сонорных) и тональных (стилизация барочной музыки) пластов буквально отражает суть конфликта - противостояние двух главных героев - Сервантеса и Дон Кихота окружающему миру агрессии и бездуховности. Образ Дон Кихота, усиленный парным персонажем - образом Сервантеса (=писателя), трактуется Альфтером как трагический, всечеловеческий, вместе с тем способный преобразовывать реальность, то есть выполняющий особое - культуротворческое назначение.

Ключевые слова: образ Дон Кихота, образ Сервантеса, тема донкихотства, испанское, полистилистика.

Насколько значимым является герой Дон Кихот для испанского народа и его культуры, свидетельствует длинный список авторов, обращавшихся к нему в своем творчестве. Среди них - С. Рамон-иКахаль, А. Кастро, С. Де Мадарьяга, М. Менендес-и-Пелайо, А. Мачадо, Ф. Гарсиа Лорка и др. Этот далеко неполный список мыслителей свидетельствуют о том, что для испанцев Дон Кихот - воплощение духа и характера испанского народа, символ нравственности и справедливости.

Если в симфонической музыке образ Дон Кихота представлен обширным списком испанских композиторов, среди которых Х. Г. Роман («Воскрешение Дон Кихота», 1994), Ф. А. Барбьери («Дон Кихот», 1861), Х. Ф. Герра («Три момента Дон Кихота», 2005), Ж. Гомбау («Дон Кихот, смотрящий оружие», 1945) и др., то в оперном искусстве данный сюжет (как ни странно) не был столь популярным.

(C) Мищук В., 2015 